\title{
Bioaccumulation of Trace Metals in Tissues of Rohu Fish for Environmental Risk
} Assessment

\author{
Nazima Noor, Bela Zutshi* \\ Department of Zoology, Bangalore University, Bangalore, India \\ Email: "bela_zutshi@yahoo.co.in
}

Received 15 February 2016; accepted 26 April 2016; published 29 April 2016

Copyright ( 2016 by authors and Scientific Research Publishing Inc.

This work is licensed under the Creative Commons Attribution International License (CC BY). http://creativecommons.org/licenses/by/4.0/

(c) (i) Open Access

\begin{abstract}
In the present study, the two lakes, Vengaiah lake (Lake A-Sewage polluted receiving discharge from storm water drain) and Yellamallappa Chetty lake (Lake B-Industrially polluted) situated near Krishnarajpuram-Hoskote taluk, Bangalore, Karnataka were selected for analysis of trace metals viz., arsenic, aluminium, cadmium, lead, mercury, iron, copper and zinc in water samples. Muscle and gill tissues of freshwater fish Labeo rohita reared in these water bodies were analysed for bioaccumulation of trace metals. Hebbal fish farm was considered as a reference site (Control site) for water and fish samples. Trace metals were analysed by atomic absorption spectroscopy and values were compared with those recommended by FAO/WHO in water and fish samples. Trace metals such as $\mathrm{Al}$, As and $\mathrm{Hg}$ were detected in the water sampled from lake B which is attributed to the differences in the sources of pollutants. Fish tissues viz., muscle and gills sampled from Lake $\mathrm{B}$ exhibited high concentration of $\mathrm{Al}, \mathrm{Pb}$ and $\mathrm{Cd}$ content showing a positive correlation with their concentration in water samples. The remaining metals as $\mathrm{Cu}, \mathrm{Zn}$ and Fe were detected in water sampled from all water bodies and also in the fish tissues. Gills exhibited higher concentration of metals in fish from lake B. Bioaccumulation of these trace metals in fish tissues may cause potential danger to human health when consumed on regular basis. Thus necessary remedial measures are required to combat water contamination and its management keeping in view the aquatic ecosystem and public health. Values were statistically significant at $P<0.0001$.
\end{abstract}

\section{Keywords}

Lake Water, Trace Metals, L. rohita, Tissues, Bioaccumulation

\footnotetext{
*Corresponding author.
} 


\section{Introduction}

Heavy metals are natural trace components of the aquatic environment, causing threat to the health of Indian ecosystem. High concentration of these metals is released into the aquatic environment as a result of leaching from bed rocks, atmospheric decomposition, water drainage, run off from river banks and discharge of urban and industrial waste waters [1]. They are among the most persistent pollutants in aquatic ecosystem because of their resistance to decomposition in natural conditions [2] and have the ability to bioaccumulate [3]; thus having public interest [4].

In recent years fish consumption has increased many folds due to its nutritional and therapeutic benefits. Fish are at the top level of aquatic food chain and are good indicators of heavy metal contamination because they accumulate metals in their tissues [5] through absorption, depending on ecological requirements, metabolisms, and other factors, such as salinity, pollution level, food, etc. Heavy metal concentration in fish tissues reflects past or present exposure [6] [7], and intake occurs mainly through the gills, skin, or by food [8]. Since metal is known to affect the central metabolic pathways it may have a major detrimental impact on both human and animal life [9], thus there is a growing concern that metals accumulated in fish tissues may represent a health risk, especially for fish consuming population [10] [11].

According to Storelli [12] metals like arsenic, cadmium, mercury and lead are toxic to biota, even in low concentrations, but other metals like $\mathrm{Cu}, \mathrm{Fe}$ and $\mathrm{Zn}$ are required for physiological activities in biological species but when taken excessively they can also produce toxic effects [13] [14]. Nord et al. [15] reported that the consumption of contaminated fish caused acute and chronic effects to humans. Monitoring heavy metal contamination in river systems by using fish tissues helps to assess the quality of aquatic ecosystems [16]. Heavy metals enter fish through five main routes (food or non-food particles, gills, water, and skin), follow into the blood, and are carried to either a storage point or to the liver for its transformation or storage [17].

Fish kill had been reported in number of lakes in Bangalore city during the past few years due to sudden discharge of effluents from various point and non-point sources into these lakes. There is a lacunae on the assessment of bioaccumulation potential of persistent organic pollutants and trace metals in the tissues of non-target animal, the fish reared in the directly affected water body. The present study was conducted to determine levels of heavy metals accumulated in water and muscle and gill tissue of $L$. rohita reared in lakes of Bangalore polluted by various sources; which were compared against the recommended BIS and PTWI by FAO/WHO to assess the quality of fish for human consumption. Muscle being an important tissue of nutritive value and gillwhich is a vital respiratory organ with their extensive surface area is directly in contact with water and xenobiotics present in water [18] and were taken as target tissues. A hypothesis that the fishes are prone to accumulate metal since they are present in the upper foodweb position and could be used as environmental indicators of large-scale aquatic ecosystem's quality was tested and thereby to evaluate the current environmental status of lake $\mathrm{A}$ and $\mathrm{B}$.

\section{Materials and Methods}

\subsection{Study Area}

Bangalore also called as Bengaluru is the capital of Karnataka state in South India (Figure 1(a)). It is located at $12.97^{\circ} \mathrm{N} 77.56^{\circ} \mathrm{E}$ and covers an area of $741 \mathrm{~km}^{2}$. The two lakes, Vengaiah lake (Lake A-Area 65 acres; depth 8 10 feet) and Yellamallappa Chetty lake (Lake B-Area 110 ha; depth 10 - 12 feet) situated near Krishnarajpuram-Hoskote taluk, Bangalore District, Karnataka were selected for the study (Figure 1(b)). Lake A received domestic sewage from an adjacent storm-water drain and Lake B those of effluents from pharma-industry and other sources. Hebbal fish farm, a reference site was taken as control which was maintained by the fisheries department.

\subsection{Sampling of Water}

Water samples were collected in the morning (8.00 to $9.00 \mathrm{am}$ ) in acid washed and dried water sampling glass bottles from control site, lake A and lake B for a period of one year (2013-2014). Trace metal such as As, $\mathrm{Cu}$, $\mathrm{Zn}, \mathrm{Al}, \mathrm{Cd}, \mathrm{Fe}, \mathrm{Pb}$ and $\mathrm{Hg}$ was analysed by Atomic Absorption Spectrometeric method [19]. Water samples were filtered using Whatman No. 41 (0.45 mm pore size) filter paper for estimation of dissolved metal content. This filtrate of the collected water samples $(500 \mathrm{ml}$ each) were preserved with $2 \mathrm{ml}$ nitric acid to prevent the 


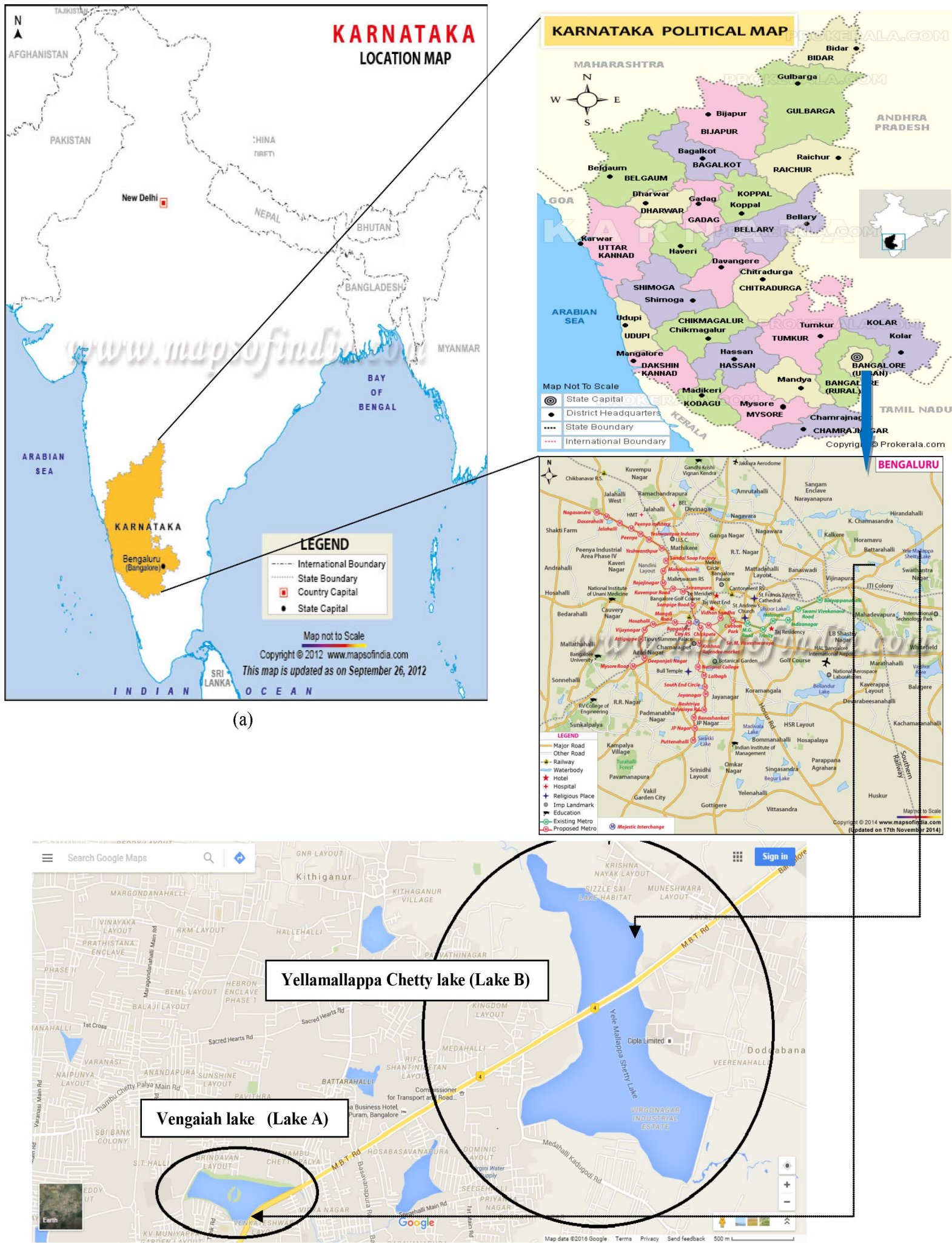

(b)

Figure 1. (a) Map of India showing location of Karnataka state and the capital city, Bangalore; (b) Representation of sampling location: Vengaiah Lake (Lake A) and Yellamallappa Chetty Lake (Lake B). 
precipitation of metals. All the samples were concentrated to tenfold on a water bath and subjected to nitric acid digestion. Trace metal analyses were carried out using flame atomic absorption spectrophotometer (Model: Perkin Elmer 3100). The calibration curves were prepared separately for all the metals by running different concentrations of standard solutions. The instrument was set to zero by running the respective reagent blanks. Average values of six replicates were taken for each determination [19]. The concentrations of heavy metals were expressed as $\mathrm{mg} / \mathrm{l}$ for water samples.

\subsection{Sampling of Fish Tissues}

Fish were anaesthetized using MS222 (Ethyl m-amino-benzoate methane sulphate) and dissected at the site itself. After dissecting, the tissues were excised, washed and preserved in $10 \%$ formalin for detection of accumulated trace metal by following the standard method [19]. The tissues were removed from formalin and dried in an oven at $80^{\circ} \mathrm{C}$ for two days. The dried tissues were grounded using a porcelain mortar and pestle. $0.1 \mathrm{~g}$ dry weight of the tissues were digested by adding $3 \mathrm{ml}$ of nitric acid (65\%) and $1 \mathrm{ml}$ hydrogen peroxide (35\%) using closed vessel microwave digestion in an oven (Hydrogen peroxide was added to the nitric acid as it reduces nitrous vapors and accelerates the digestion of organic matter by raising the temperature). The digested samples were transferred to clean volumetric flasks, diluted to $50 \mathrm{ml}$ with deionized water and filtered using Whatman filter paper $(0.45 \mu \mathrm{m})$. Concentrations of different metals were determined by using atomic absorption spectrophotometer Model: Perkin Elmer 3100. Sample blanks were prepared in the similar way as the test samples for background correction. Standard solutions were prepared from stock solutions as per the requirement of metal extraction. The concentrations of heavy metals were expressed as $\mu \mathrm{g} / \mathrm{g}$ dry weight of tissues.

\subsection{Statistical Analysis}

Statistical analysis was carried by using MS Excel and statistical software-Graphpad prism to evaluate the metal content with respect to three water bodies and tissues of fish. Mean of the water and tissue sample size $(n=6)$ and standard deviation (mean \pm SD) was conducted to quantify their variability which was followed by one way ANOVA to compare significant mean differences of the above mentioned groups. This was followed by Tukey's post-hoc test to compare pair of groups mean of each metal in water and with its bioaccumulation in fish tissue of control group, lake A and lake B. $p$ value at a significant level of $p<0.05$ or less indicated significant relationship within variables. Pearson's correlation coefficient between metal concentration in lake water (A \& B) and muscle and gill tissue of fish were also studied.

\section{Result}

Analyses of trace metals content in the three water bodies-Hebbal Fishfarm (control), Vengaiah Lake (A) and Yellamallappa Chetty Lake (B) during the period of study are shown in Table 1.

\subsection{Trace Metal Content in Water Samples}

Water samples from control site was analysed for the presence of trace metals. The results showed the presence of $\mathrm{Cu}, \mathrm{Zn}$ and $\mathrm{Fe}$ within BIS limits whereas, $\mathrm{As}, \mathrm{Al}, \mathrm{Cd}, \mathrm{Pb}$ and $\mathrm{Hg}$ were not detected. The concentration of trace metals such as $\mathrm{Cu}, \mathrm{Zn}$ and Fe showed higher levels $(0.25 \pm 0.01,3.12 \pm 0.01$ and $3.02 \pm 0.006$ respectively) in lake $\mathrm{B}$ when compared to those of lake A $(0.03,1.67 \pm 0.01$ and $0.11 \pm 0.008$ respectively) and control. Fe content was recorded above BIS limits in lake B. Hg was observed below detectable limits in water sampled from lake A but showed its presence of $0.023 \mathrm{mg} / \mathrm{l}$ in lake B which was above BIS limit $(0.001 \mathrm{mg} / \mathrm{l})$. Trace metals viz., $\mathrm{As}, \mathrm{Al}, \mathrm{Cd}$ and $\mathrm{Pb}$ were recorded below detectable level in water sampled from control site but they were within BIS limits in lake A (As-0.001; $\mathrm{Cd}-0.04 \pm 0.01$; $\mathrm{Pb}-0.04 \pm 0.008$ ) with the exception of Al $(0.067 \pm 0.001)$ which was above BIS limits. The concentration of these groups of trace metal was recorded higher in water sampled from Lake B when compared to those of lake A. The concentration of $\mathrm{Al}, \mathrm{Cd}$ and $\mathrm{Pb}$ ( $3.7 \pm 0.089,0.124$ and 0.23 respectively) were above BIS limits in lake B.

\subsection{Bioaccumulation of Trace Metals in Tissues}

The presence of these metals in water beyond BIS limits as in the present work might affect the general metabolism 
and enzyme activity in fish as was recorded by various scientists. Therefore, in the present investigation, analyses of heavy metals were conducted in muscle and gill tissues sampled from control site, lake A and lake B (Table 2). As, $\mathrm{Hg}, \mathrm{Al}, \mathrm{Cd}$, and $\mathrm{Pb}$ levels were recorded below detectable limit in both muscle and gill tissues in fish sampled from control site, lake $\mathrm{A}$ and $\mathrm{B}$ but with exception of $\mathrm{Al}, \mathrm{Cd}$ and $\mathrm{Pb}$ which were detected in lake $\mathrm{B}$ only but As and $\mathrm{Hg}$ were recorded below detectable limit in both fish tissues from lake B. Significantly higher accumulation of $\mathrm{Cu}, \mathrm{Zn}, \mathrm{Fe}, \mathrm{Al}, \mathrm{Cd}$, and $\mathrm{Pb}$ was observed in muscle and gill tissues sampled from lake $\mathrm{B}$. $\mathrm{Al}, \mathrm{Cd}$ and $\mathrm{Pb}$ showed accumulation of $2.18 \pm 0.14 ; 0.41 \pm 0.50 ; 0.15 \pm 0.04$ (in muscle) and $3.81 \pm 0.17 ; 0.24 \pm 0.02$; $0.26 \pm 0.02$ (in gill) tissue in fish from lake B which were undetectable in tissues from control site and lake A. $\mathrm{Cu}, \mathrm{Zn}$ and Fe showed highest accumulation in both muscle (2.89 $\pm 0.12 ; 13.65 \pm 0.30 ; 73.01 \pm 0.52)$ and gill (5.02 $\pm 0.18 ; 43.71 \pm 0.42$; $93.71 \pm 0.63$ ) tissue from lake B when compared to lake A and control site. Such accumulation of trace metals- $\mathrm{Cu}, \mathrm{Zn}$ and Fe in muscle $(1.40 \pm 0.29,6.32 \pm 0.39$ and $28.91 \pm 0.40)$ and gill $(3.62 \pm 0.16,19.78 \pm 0.32$ and $66.02 \pm 0.82)$ tissues sampled from lake A were significantly higher when compared to those of control site.

Table 1. Trace metals in water sampled from Hebbal fishfarm (Control site), Vengaiah Lake (Lake A) and Yellamallappa Chetty Lake (Lake B).

\begin{tabular}{|c|c|c|c|c|}
\hline Parameters & $\begin{array}{l}\text { BIS: 10500-1991 } \\
\text { (Revised 2012) }\end{array}$ & Control site & Lake A & Lake B \\
\hline Arsenic & 0.05 & 0 & 0.001 & $0.003^{\mathrm{a}}$ \\
\hline Mercury & 0.001 & 0 & 0 & 0.023 \\
\hline Aluminium & $0.03-0.2$ & 0 & $0.067 \pm 0.001^{\mathrm{a}}$ & $3.7 \pm 0.089^{\mathrm{a}}$ \\
\hline Cadmium & 0.01 & 0 & $0.04 \pm 0.01^{\mathrm{d}}$ & $0.124^{\mathrm{a}}$ \\
\hline Lead & 0.05 & 0 & $0.04 \pm 0.008^{\mathrm{d}}$ & $0.23^{\mathrm{a}}$ \\
\hline Copper & $0.05-1.5$ & 0.01 & $0.03^{\mathrm{a}}$ & $0.25 \pm 0.01^{\mathrm{a}}$ \\
\hline Zinc & $5-15$ & $0.54 \pm 0.02$ & $1.67 \pm 0.01^{\mathrm{a}}$ & $3.12 \pm 0.01^{\mathrm{a}}$ \\
\hline Iron & $0.3-1$ & $0.04 \pm 0.01$ & $0.11 \pm 0.008^{\mathrm{a}}$ & $3.02 \pm 0.006^{\mathrm{a}}$ \\
\hline
\end{tabular}

Values are expressed in mg/l. Values are expressed as mean \pm SD where, $\mathrm{n}=6$ and "0” indicates BDL. The superscripts a, b, c and $\mathrm{d}$ indicate statistical mean differences at $\mathrm{p}<0.0001,0.001,0.01$ and 0.05 respectively.

Table 2. Trace metal content in muscle and gill tissues of Labeo rohita sampled from Hebbal Fishfarm (Control site), Vengaiah Lake (Lake A) and Yellamallappa Chetty Lake (Lake B).

\begin{tabular}{ccccccc}
\hline \multirow{2}{*}{ Parameters } & \multicolumn{3}{c}{ Muscle } & \multicolumn{2}{c}{ Gill } \\
\cline { 2 - 7 } & Control site & Lake A & Lake B & Control site & Lake A & Lake B \\
\hline Arsenic & 0.00 & 0.00 & 0.00 & 0.00 & 0.00 & 0.00 \\
Mercury & 0.00 & 0.00 & 0.00 & 0.00 & 0.00 & 0.00 \\
Aluminium & 0.00 & 0.00 & $2.18 \pm 0.14^{\mathrm{a}}$ & 0.00 & 0.00 & $3.81 \pm 0.17^{\mathrm{a}}$ \\
Cadmium & 0.00 & 0.00 & $0.41 \pm 0.50^{\mathrm{a}}$ & 0.00 & 0.00 & $0.24 \pm 0.02$ \\
Lead & 0.00 & 0.00 & $0.15 \pm 0.04^{\mathrm{a}}$ & 0.00 & 0.00 & $0.26 \pm 0.02^{\mathrm{a}}$ \\
Copper & $1.13 \pm 0.12$ & $1.40 \pm 0.29$ & $2.89 \pm 0.12^{\mathrm{a}}$ & $2.10 \pm 0.08$ & $3.62 \pm 0.16^{\mathrm{a}}$ & $5.02 \pm 0.18^{\mathrm{a}}$ \\
Zinc & $4.22 \pm 0.21$ & $6.32 \pm 0.39^{\mathrm{a}}$ & $13.65 \pm 0.30^{\mathrm{a}}$ & $16.30 \pm 0.49$ & $19.78 \pm 0.32^{\mathrm{a}}$ & $43.71 \pm 0.42^{\mathrm{a}}$ \\
Iron & $21.59 \pm 0.51$ & $28.91 \pm 0.40^{\mathrm{a}}$ & $73.01 \pm 0.52^{\mathrm{a}}$ & $61.65 \pm 1.03$ & $66.02 \pm 0.82^{\mathrm{a}}$ & $93.71 \pm 0.63^{\mathrm{a}}$ \\
\hline
\end{tabular}

Values are expressed in $\mu \mathrm{g} / \mathrm{g}$ dry weight of tissues and as mean $\pm \mathrm{SD}$ where, $\mathrm{n}=6$. " 0 ” indicates BDL. The superscripts a, b, c and d indicate statistical mean differences at $\mathrm{p}<0.0001,0.001,0.01$ and 0.05 respectively. 


\section{Discussion}

Trace metals including both essential and non-essential elements have a particular significance in eco-toxicology, since they are highly persistent having potential to be toxic to living organisms [20] [21]. García-Medina et al. [22] have reported that dissolved aluminium in water induced genotoxic and cytotoxic effects on the lymphocytes of carp (Cyprinus carpio). The present results on Al content detected in lake B and in fish muscle and gill tissue are in conformity with those of Jabeen et al. [23] suggesting significantly high fluctuations in aluminium content in tissues of Catla catla, Labeo rohita and Cirrhina mrigala collected from river Ravi, Pakistan with respect to pollution level. Alwan [24] reported that the stimulation of erythropoiesis or the disturbances that occurred in both metabolic and hemopoietic activities of fish exposed to sub lethal concentrations of aluminium are defense reaction against toxicity of aluminium.

Presence of cadmium in water and its significant levels in fish tissues (muscle \& gills) from lake B may cause disturbances in respiration as was also observed in tuna exposed for a short term period to cadmium by Witeska et al. [25]. This trace metal affects the physiology of fish due to its chronic exposure to waterborne sub-lethal levels cadmium as suggested by Ricard et al. [26] in the rainbow trout and by Abedi et al. [27] in common carp. Acute toxicity studies of cadmium on the edible carp, Catla catla conducted by Sobha et al. [28] revealed significant changes in the biochemical constituents of the fish like glucose, glycogen, total proteins, lipids and free amino acids. Reports by Abdel-Moneim et al. [29] on gills and liver of Oreochromis niloticus from polluted wetland environments, Saudi Arabia showed that bioaccumulation of Cd were mostly above the WHO reference values. These results are in agreement with the present study.

In the present study bioaccumulation of lead was detected in muscle and gill tissue of fish sampled from lake $\mathrm{B}$ since lead was recorded in significantly high concentration in lake $\mathrm{B}$. $\mathrm{Pb}$, and $\mathrm{Cd}$ are not nutrients at trace levels and are non-essential, so they are recognized as important industrial hazards, causing severe toxic effects in higher animals upon acute or chronic exposure. Stomiñska and Jezierska [30] studied Common carp larvae under laboratory conditions, in water containing lead or copper. Exposure to heavy metals resulted in slowed down development and growth rate, and reduced survival. Exposure to lead caused scoliosis. The WHO provisional guideline of $0.2 \mathrm{mg} / \mathrm{L}, 0.003 \mathrm{mg} / \mathrm{L} \& 0.01 \mathrm{mg} / \mathrm{L}$ for aluminium, cadmium \& lead respectively has been adopted as the standard for drinking water [31].

Copper, Zinc and Iron was detected in the water sampled from control site as well as lake A \& B but was well within the BIS desired range. Even though these metals are essential element in low concentrations but when discharged into the freshwater environments in higher concentrations, copper is reported to cause severe effects on the freshwater fauna, especially fishes [32] and zinc caused oxidative stress in estuarine teleostean, Fundulus heteroclitus [33]. The high level of Fe in the fish species could be attributed to its bioavailability in the environment and its essential role in haemoglobin [34]. In present study bioaccumulation of all the three metals was observed more in muscle and gill tissues of $L$. rohita from lake B but was very less when compared to the dietary intake limits. Similar observations of bioaccumulation of metals were reported by Jabeen et al. [23] in gills, liver, kidney, muscle, fins and other tissues from fish, C. catla, L. rohita and Cirrhina mrigala collected from three sampling stations of river Ravi, Pakistan and by Samir and Ibrahim [35] in Oreochromis niloticus sampled from the northern delta lakes in Egypt. Subathra and Karuppasamy [36] observed maximum level of Cu in liver compared to other organs like kidney, muscle and gill in Mystus vittatus when subjected to sublethal concentration of this heavy metal. There is evidence that exposure of salmon to sublethal copper levels causes toxicity and results in the impairing osmoregulation and ion regulation in their gills with a loss of chemosensory function, which affects predator-avoidance behavior [37]. Exchangeable iron ( $\mathrm{Fe}$ ) usually relates to the adsorbed metals on the sediment surface can be easily remobilized into the Lake water [38]. Iron toxicity caused reduced growth rate in the Indian major carps like rohu and catla [39]. The WHO provisional guideline of $2 \mathrm{mg} / \mathrm{L}, 3 \mathrm{mg} / \mathrm{L} \& 0.3$ $\mathrm{mg} / \mathrm{L}$ for copper, zinc \& iron respectively has been adopted as the standard for drinking water [31].

In the present study, variation in trace metals content is attributed to the differences in the sources of pollutants discharged into the lakes and statistical mean differences were significant at $\mathrm{p}<0.0001$. Trace metal content in the tissues studied exhibited a positive correlation with their concentration in water samples. Although the values of bioaccumulated trace metals in fish tissues were not high but they may pose a potential danger to the public health in future depending on sources of pollution and its exposure time period. The extent of bioaccumulation of metals in tissues of fish is dependent on its total amount and bioavailability of each metal in the environmental medium, the route of uptake, storage and excretory mechanisms [40] [41]. 
A number of serious health problems can develop as a result of excessive uptake of dietary heavy metals. The Joint FAO/WHO expert committee on food additives established a PTWI for aluminium of $1 \mathrm{mg} / \mathrm{kg} / \mathrm{body}-$ weight/week, for cadmium as $0.007 \mathrm{mg} / \mathrm{kg}$ body weight and for lead as $0.025 \mathrm{mg} / \mathrm{kg}$ body weight [42]. The estimated adult dietary intakes of copper in man are between 2 and $4 \mathrm{mg} /$ day, and PTWI (Provisional tolerable weekly intake) for zinc is $7 \mathrm{mg} / \mathrm{kg} /$ bodyweight/week and for iron is $5.6 \mathrm{mg} / \mathrm{kg} /$ week [42]. Furthermore, the consumption of heavy metal-contaminated food can seriously deplete some essential nutrients in the body causing a decrease in immunological defense, intrauterine growth retardation, impaired psycho-social behaviors, disabilities associated with malnutrition and a high prevalence of upper gastrointestinal cancer [43].

With respect to the human health, $\mathrm{Al}$ was recorded to be poisonous if it crossed the permissible limits causing various ailments such as Alzheimer's disease [44] [45]. Similarly cadmium accumulates in the human body by consuming plant- and animal-based foods, affecting several organs: liver, kidney, lung, bones, placenta, and central nervous system negatively [46]-[48] and reproductive development, hepatic, haematological and immunological damages [49] [50] and lead can pose a serious health risk to adult and children resulting in delayed physical and mental development and slight deficit and learning abilities [51]. Ingestion of high levels of copper salts is known to cause gastrointestinal upsets and zinc to damage many biochemical processes followed by its deposition in the kidneys, liver, gonads [45]. Iron is found in natural fresh and ground water, but have no health based guideline value, although high concentrations gave rise to consumer complaints due to its ability to discolour aerobic waters at concentrations above $0.3 \mathrm{mg} / \mathrm{L}$ [31].

It has been predicted that fish consumption in developing countries will increase by 57 percent, from 62.7 million tons in 1997 to 98.6 million in 2020 [52], since fish flesh provides an excellent source of nutrition for human. Thus necessary remedial measures are required to combat water contamination and its management keeping in view the public health and the aquatic ecosystem.

\section{Conclusion}

On the basis of present investigation of two lakes, the metal content was higher than standard BIS and WHO limits in the water sampled from Lake B since toxins and trace metals were drained into this lake from the adjacent pharma company and thus can be considered as the more polluted site. The results also revealed that metals were absorbed by the fish showing varied accumulation between two tissues of fish sampled from Lake B. Comparatively higher values were exhibited in gills than muscles which can be attributed to their physiological functioning. Muscle, an edible part of the fish indicated safe levels for human consumption and such concentrations were less than the PTWI as suggested by Joint FAO/WHO Expert Committee on Food Additives. However the trace metals load should be continuously monitored in this lake as it can result in potential damage in the form of toxicological effect on aquatic and human health in the near future.

\section{References}

[1] Rabee, A.M.., Yaaroub, F.F. and Mustafa, N. (2011) Assessment of Heavy Metal Pollution in Tigis River Sediment in Baghdad Region. Journal of Al Nahrain University-Science, 14, 108-114.

[2] Khan, A.T. (2011) Trace Element in the Drinking Water and Their Possible Health Effect in Aligarh City. Journal of Water Resource and Protection, 3, 522-530. http://dx.doi.org/10.4236/jwarp.2011.37062

[3] Censi, P., Spoto, S.E., Saiano, F., Sprovieri, M., Mazzola, S., Nardone G., Geronimo, D., Punturo, R. and Ottonello, D. (2006) Heavy Metals in Coastal Water Systems. A Case Study from the Northwestern Gulf of Thailand. Chemosphere, 64, 1167-1176. http://dx.doi.org/10.1016/j.chemosphere.2005.11.008

[4] Niemi, G.J., Devore, P., Detenbeck, N., Taylor, D., Lima, A., Pastor, J., Yount, J.D. and Naiman, R.J. (1990) Overview of Case Studies on Recovery of Aquatic Systems from Disturbance. Environmental Management, 14, 571-587. http://dx.doi.org/10.1007/BF02394710

[5] Yilmaz, F., Ozdemir, N., Demirak, A. and Tuna, A.L. (2007) Heavy Metal Levels in Two Fish Species Leuciscus cephalus and Lepomis gibbosus. Food Chemistry, 100, 830-835. http://dx.doi.org/10.1016/j.foodchem.2005.09.020

[6] Canli, M., Ay, O. and Kalay, M. (1998) Levels of Heavy Metals (Cd, Pb, Cr and Ni) in Tissue of Cyprinus carpio, Barbus capito and Chondrostoma regium from the Seyhan River, Turkey. Turkish Journal of Zoology, 22, 149-157.

[7] Henry, F., Amara, R., Courcot, L., Lacouture, D. and Bertho, M.L. (2004) Heavy Metals in Four Fish Species from the French Coast of the Eastern English Channel and Southern Bight of the North Sea. Environmental International, 30, 675-683. http://dx.doi.org/10.1016/j.envint.2003.12.007 
[8] Bordajandi, L.R., Gómez, G., Fernández, M.A., Abad, E., Rivera, J. and González, M.J. (2003) Study on PCBs, PCDD/Fs, Organochlorine Pesticides, Heavy Metals and Arsenic Content in Freshwater Fish Species from the River Turia (Spain). Chemosphere, 53, 163-171. http://dx.doi.org/10.1016/S0045-6535(03)00417-X

[9] Pandey, S., Parvez, S., Ansari, R.A., Ali, M., Kaur, M., Hayat, F., Ahmad, F. and Raisuddin, S. (2008) Effects of Exposure to Multiple Trace Metals in Biochemical Histological and Ultrastructural Features of Gills of a Freshwater Fish, Channa punctata Bloch. Chemico-Biological Interactions, 174, 183-192. http://dx.doi.org/10.1016/j.cbi.2008.05.014

[10] Burger, J. and Gochfeld, M. (2009) Perceptions of the Risks and Benefits of Fish Consumption: Individual Choices to Reduce Risk and Increase Health Benefits. Environmental Research, 109, 343-349. http://dx.doi.org/10.1016/j.envres.2008.12.002

[11] Ling, M.P., Hsu, H.T., Shie, R.H., Wu, C.C. and Hong, Y.S. (2009) Health Risk of Consuming Heavy Metals in Farmed Tilapia in Central Taiwan. Bulletin of Environmental Contamination and Toxicology, 83, 558-564. http://dx.doi.org/10.1007/s00128-009-9829-y

[12] Storelli, M.M. (2008) Potential Human Health Risks from Metals (Hg, Cd, and Pb) and Polychlorinated Biphenyls (PCBs) via Seafood Consumption: Estimation of Target Hazard Quotients (THQs) and Toxic Equivalents (TEQs). Food and Chemical Toxicology, 46, 2782-2788. http://dx.doi.org/10.1016/j.fct.2008.05.011

[13] Mallin, M.A., McIver, M.R., Fulton, M. and Wirth, E. (2011) Elevated Levels of Metals and Organic Pollutants in Fish and Clams in the Cape Fear River Watershed. Archives of Environmental Contamination and Toxicology, 61, 461-471. http://dx.doi.org/10.1007/s00244-010-9633-z

[14] Turyk, M.E., Bhavsar, S.P., Bowerman, W., Boysen, E., Clark, M., et al. (2012) Risks and Benefits of Consumption of Great Lakes Fish. Environmental Health Perspectives, 120, 11-18. http://dx.doi.org/10.1289/ehp.1003396

[15] Gale, N.L., Adams, C.D., Wixson, B.G., Loftin, K.A. and Huang, Y.-W. (2004) Lead, Zinc, Copper and Cadmium in Fish and Sediments from the Big River Creek of Missouri’s Old Lead Belt. Environmental Geochemistry and Health, 26, 37-49. http://dx.doi.org/10.1023/B:EGAH.0000020935.89794.57

[16] Jabeen, F. and Chaudhry, A.S. (2010) Environmental Impacts of Anthropogenic Activities on the Mineral Uptake in Oreochromis mossambicus from Indus River in Pakistan. Environmental Monitoring and Assessment, 166, 641-651. http://dx.doi.org/10.1007/s10661-009-1029-z

[17] Adam, S.M. (2002) Biological Indicators of Aquatic Ecosystem Stress. American Fisheries Society, Bethesda, 656.

[18] Jiang, H., Yang, H., Kong, X., Wang, S., Liu, D. and Shi, S. (2012) Response of Acid and Alkaline Phosphatase Activities to Copper Exposure and Recovery in Freshwater Fish Carassius auratus gibelio var. Life Science Journal, 9, 233-245.

[19] USEPA-United States Environmental Protection Agency (1983) Metals (Atomic Absorption Methods)—General Procedure for Analysis by Atomic Absorption. In: Methods for the Chemical Analysis of Water and Wastes, EPA600/4-79-020, US Environmental Protection Agency, Cincinnati, 202-289.

[20] Storelli, M.M., Storelli, A., D’ddabbo, R., Marano, C., Bruno, R. and Marcotrigiano, G.O. (2005) Trace Elements in Loggerhead Turtles (Caretta caretta) from the Eastern Mediterranean Sea: Overview and Evaluation. Environmental Pollution, 135, 163-170. http://dx.doi.org/10.1016/j.envpol.2004.09.005

[21] Agatha, A.N. (2010) Levels of Some Heavy Metals in Tissues of Bonga Fish, Ethmallosa fimbriata from Forcados River. Journal of Applied Environmental and Biological Sciences, 1, 44-47.

[22] García-Medina, S., Razo-Estrada, C., Galar-Martinez, M., Cortéz-Barberena, E., Gómez-Oliván, L.M., AlvarezGonzález, I. and Madrigal-Bujaidar, E. (2011) Genotoxic and Cytotoxic Effects Induced by Aluminum in the Lymphocytes of the Common Carp, Cyprinus carpio. Comparative Biochemistry and Physiology Part C: Toxicology \& Pharmacology, 153, 113-118. http://dx.doi.org/10.1016/j.cbpc.2010.09.005

[23] Jabeen, G., Javed, M. and Azmat, H. (2012) Assessment of Heavy Metals in the Fish Collected from the River Ravi, Pakistan. Pakistan Veterinary Journal, 32, 107-111.

[24] Alwan, S.F. (2013) Effect of Aluminium Exposure on Some Blood Parameters in the Tilapia zillii Fish. International Journal of Pharmacy and Life Sciences, 4, 2766-2769.

[25] Witeska, M., Jezierska, B. and Wolnieki, J. (2006) Respiratory and Hematological Response of Tench, Tinca tinca (L.) to a Short-Term Cadmium Exposure. Aquaculture International, 14, 141-152. http://dx.doi.org/10.1007/s10499-005-9020-3

[26] Ricard, A.C., Daniel, C., Anderson, P. and Hontela, A. (1998) Effects of Subchronic Exposure to Cadmium Chloride on Endocrine and Metabolic Functions in Rainbow Trout Oncorhynchus mykiss. Archives of Environmental Contamination and Toxicology, 34, 377-381. http://dx.doi.org/10.1007/s002449900333

[27] Abedi, Z., Hasantabar, F., Mohammad, A., Khalesi, K. and Babaei, S. (2013) Effect of Sublethal Concentrations of Cadmium, Lead and Chromium on Some Enzymatic Activities of Common Carp; Cyprinus carpio. World Journal of Zoology, 8, 98-105. 
[28] Sobha, K., Poornima, A., Harini, P. and Veeraiah, K. (2007) A Study on Biochemical Changes in the Fresh Water Fish, Catla catla (Hamilton) Exposed to the Heavy Metal Toxicant Cadmium Chloride. Kathmandu University Journal of Science, Engineering and Technology, 3, 1-11.

[29] Abdel-Moneim, A.M., Al-Kahtani, M.A. and Elmenshawy, O.M. (2012) .Histopathological Biomarkers in Gills and Liver of Oreochromis niloticus from Polluted Wetland Environments, Saudi Arabia. Chemosphere, 88, 1028-1035. http://dx.doi.org/10.1016/j.chemosphere.2012.04.001

[30] Stomiñska, I. and Jezierska, B. (2000) The Effect of Heavy Metals on Post Embryonic Development of Common Carp, Cyprinus carpio L. Archives of Polish Fisheries, 8, 119-128.

[31] WHO (2004) Guidelines for Drinking-Water Quality. 61st Meeting, Rome, 10-19 June 2003, Joint FAO/WHO Expert Committee on Food Additives. http://ftp.fao.org/es/esn/jecfa/jecfa61sc.pdf

[32] Lodhi, H.S., Khan, M.A., Verma, R.S. and Sharma, U.D. (2006) Acute Toxicity of Copper Sulphate to Fresh Water Prawns. Journal of Environmental Biology, 27, 585-588.

[33] Loro, V.L., Jorge, M.B., da Silva, K.R. and Wood, C.M. (2012) Oxidative Stress Parameters and Antioxidant Response to Sublethal Waterborne Zinc in a Euryhaline Teleost Fundulus heteroclitus: Protective Effects of Salinity. Aquatic Toxicology, 110-111, 187-193. http://dx.doi.org/10.1016/j.aquatox.2012.01.012

[34] Eneji, I.S., Ato, R.S. and Annune, P.A. (2011) Bioaccumulation of Heavy Metals in Fish (Tilapia zilli and Clarias gariepinus) Organs from River Benue, North-Central Nigeria. Pakistan Journal of Analytical \& Environmental Chemistry, 12, 25-31.

[35] Samir, M.S. and Ibrahim, M.S. (2008) Assessment of Heavy Metals Pollution in Water and Sediments and Their Effect on Oreochromis niloticus in the Northern Delta Lakes, Egypt. 8th International Symposium on Tilapia in Aquaculture, Cairo, 12-14 October 2008, 475-489.

[36] Subathra, S. and Karuppasamy, R. (2008) Bioaccumulation and Depuration Pattern of Copper in Different Tissues of Mystus vittatus, Related to Various Size Groups. Archives of Environmental Contamination and Toxicology, 54, 236244. http://dx.doi.org/10.1007/s00244-007-9028-y

[37] McIntyre, J.K., Baldwin, D.H., Meador, J.P. and Scholz, N.L. (2008) Chemosensory Deprivation in Juvenile Coho Salmon Exposed to Dissolved Copper under Varying Water Chemistry Conditions. Environmental Science \& Technology, 42, 1352-1358. http://dx.doi.org/10.1021/es071603e

[38] Ikem, A., Egiebor, N.O. and Nyavor, K. (2003) Trace Elements in Water, Fish and Sediment from Tuskegee Lake, South-Eastern USA. Water, Air, \& Soil Pollution, 149, 51-75. http://dx.doi.org/10.1023/A:1025694315763

[39] Debnath, M. (2011) Effects of Water Borne Iron on Spawn and Fry of Indian Major Carps in Tripura. MFSc Thesis, Department of Fish Health \& Environment, College of Fisheries, Central Agricultural University, Iroisemba.

[40] Rand, G.M. and Petrocelli, S.R., Eds. (1985) Fundamentals of Aquatic Toxicology: Methods and Applications. Hemispheres Publishing, New York, 374-415.

[41] Chapman, P.M., Allen, H.E. and Z’Graggen, M.N. (1996) Evaluation of Bioaccumulation Factors in Regulating Metals. Environmental Science \& Technology, 30, 448-452. http://dx.doi.org/10.1021/es962436d

[42] JECFA- Joint FAO/WHO Expert Committee on Food Additives. (2004) Safety Evaluation of Certain Food Additives and Contaminants. WHO Food Additives Series, No. 52.

[43] Arora, M., Kiran, B., Rani, S., Rani, A., Kaur, B. and Mittal, N. (2008) Heavy Metal Accumulation in Vegetables Irrigated with Water from Different Sources. Food Chemistry, 11, 811-815. http://dx.doi.org/10.1016/j.foodchem.2008.04.049

[44] Rondeau, V., Commenges, D., Jacqmin, H.G. and Dartigues, J.F. (2000) Relations between Aluminium Concentrations in Drinking Water and Alzheimer's Disease. American Journal of Epidemiology, 152, 59-66. http://dx.doi.org/10.1093/aje/152.1.59

[45] Hubicki, Z. and Kołodyńska, D. (2012) Selective Removal of Heavy Metal Ions from Waters and Waste Waters Using ion Exchange Methods. In: Kilislioğlu, A., Ed., Ion Exchange Technologies. http://www.intechopen.com/books/ion-exchange-technologies/selective-removal-of-heavy-metal-ions-from-waters-and -waste-waters-using-ion-exchange-methods

[46] WHO (2004) Evaluation of Certain Food Additives Contaminants. Sixty-First Report of the Joint FAO/WHO Expert Committee on Food Additives, WHO Technical Report Series, No. 922.

[47] WHO (2006) Evaluation of Certain Food Contaminants. Sixty-Fourth Report of the Joint FAO/WHO Expert Committee on Food Additives, WHO Technical Report Series, No. 930.

[48] Castro-González, M.I. and Méndez-Armenta, M. (2008) Heavy Metals: Implications Associated to Fish Consumption. Environmental Toxicology \& Pharmacology, 26, 263-271. http://dx.doi.org/10.1016/j.etap.2008.06.001

[49] ATSDR - Agency for Toxic Substance and Disease Registry (2008) Draft Toxicological Profile for Cadmium U.S. Department of Health and Humans Services, Public Health Humans Services, Centers for Diseases Control, Atlanta. 
[50] Apostoli, P. and Catalani, S. (2011) Metal Ions Affecting Reproduction and Development. Metal Ions in Life Science, 8, 263-303.

[51] USEPA-United States Environmental Protection Agency (1986) Quality Criteria for Water. United States Environmental Protection Agency office of Water Regulations and Standards, Washington DC, 20460.

[52] Retnam, A. and Zakaria, M. (2010) Hydrocarbons and Heavy Metals Pollutants in Aquaculture. http://psasir.upm.edu.my/5601/1/5.pdf 